\title{
The Analysis of Dalian Special Tourism Souvenirs
}

\author{
Ming Zhu \\ Lecturer of Art College, Dalian Jiaotong University, China
}

\begin{abstract}
Dalian is an important coastal port city and also famous for tourist. It makes an analysis in this paper based on the current problems in design and openness of Dalian tourism souvenir market, and after discussing about the concept and resdisearch significance of souvenir, it reserches on the designing and developing ideas of Dalian tourism souvenirs with the development of tourism industry in order to increase recognition of the coastal city- Dalian.
\end{abstract}

Index Terms - Dalian, Tourist Souvenirs, Design and Development

According to the statistics by Dalian Municipal Bureau of Statistics (NBS) in 2011, the total number of the reception of tourism of the year are 43.776 million, the revenue reached $¥ 65.02$ billion RMB. The income of tourism industry is an important part of the economic income of the city. Dalian is located in the southernmost tip of Liaodong peninsula in northeast China, it is an important coastal port city and also famous for tourist.

Dalian has tourism resources with particularly favourable natural conditions, for it is surrounded by sea on three sides, faces Yellow Sea in the east, Bo sea in the west, and Shandong Peninsula in the south and Northeast Plain in the north. With rich marine resources, it is an important tourist city with port trade and industrial as a whole. It has a reputation of "Romantic and fashion city". There are hundreds of squares in sizes here, such as the "Friendly Square" which can represent the Sino-Soviet friendship. There are more than 10 festival days with Dalian representative, such as the festival of Locust, International Garments, Pedestrianism, Changhai International Fishing etc.. The theme parks are also colorful, such as the Ocean Park, the Forest Zoo, the Kingdom of Discovery etc. which built by the sea, they have attracted many both domestic and foreign tourists. Dalian is a fashion and romantic city, but also has a long historical culture, such as the Dahe Hotel, Sino-Soviet Friendship Hotel etc. which in Lvshunkou of Dalian, the history of Lvshunkou can be traced back to about five thousand years ago. Dalian is not only a coastal city, but also the land of fruit and hot spring at the same time. There are many kinds of fruit here, such as large cherry, blueberry, apple, peach, persimmon, jujube, grape, etc.. Dalian has a resource of hot spring in underground, it also offers a new development opportunity for the tourism which use the hot spring as a theme with comfort climate and four distinctive seasons.

Tourism souvenir is an important constituent in the field of tourism, and also one of the main economic incomes in tourism industry. At present, compared with the development of tourism, the tourist souvenirs is lagging behind. At the same time, the development of tourism souvenirs in some projects, such as the hot spring tourism and picking tourism is still blank.

\section{The Definition and Essential Characteristics of Tourist Souvenirs}

Tourist souvenirs, just as its name implies, is the goods that bought by people in the process of tourism with local characteristics. The goods should have the function of memorialize, and can reflect the features of local natural and humanities characteristic, they can be food, handicrafts, and also digital products etc. Tourism souvenirs have more interesting and self-independence than other parts of the tourism industry, such as tickets, accommodation geometric.

Today, the ways of carrier, form and sale have changed greatly of tourist souvenirs. With the improvement of science and educational level of consumers, the request for tourism products have improved, not only the traditional crafts. In terms of the carrier, from traditional crafts to today's digital imaging products. In forms, from tourist attractions at beginning to today's theme park, hot springs, fruit and vegetable picking, leisure farms and other characteristics, in sales, with the advent of the Internet era, not constrained in the field of fixed sales model, such as the Chinese characteristics in Taobao, making the marketing way more diverse. At the same time, with the application of digital technology, field trips can also be converted into virtual ones, people can travel in virtual cities and buy goods through virtual network without leaving home.

\section{The Significance of Tourism Souvenirs Design and Development}

"Tourist Souvenirs" is a kind of goods with special value, it has a great significance to research the tourist souvenirs' design and development. It can be image symbols of a tourism city, tourist area, tourist attractions, and can also be the goods with collection and presentation value.

Firstly, "tourist souvenirs" is a cultural transmission. Local cultural heritage and urban features can be embodied through it. Lvshun Naval Port is one of the five famous naval ports in the world during the period of Qing government, up to now, still an open-air museum in modem history of China and even the world. We can convey the history and culture of Dalian through souvenirs, letting more people know the city.

Secondly, "tourist souvenirs" can promote the development of economy. It is closely related to many fields of a souvenir from design to production for marketing and to the hands of collectors, such as design, production, sales, logistics field, including the Internet, etc. and can also solve the employment and products exported problems.

Thirdly, achieve consumers' own demands. Such as personal needs, memorialize or gift demands etc. 


\section{Present Situation of Dalian Tourism Souvenir}

At present, it is mainly composed of two kinds of goods at souvenir point of sales of scenic spots in Dalian, the traditional crafts souvenirs and food. Traditional crafts souvenirs are mainly contain the common shells, pearl jewelry, starfish products and marine simulation plush toys. The materials and modeling are both based on the ocean. Food is given priority to seafood, such as squid silk, fillets, dried scallops, abalone, sea cucumber, etc. These two kinds of goods are generally the same in the coastal cities, such as Qingdao, Yantai, Haikou and other coastal cities. Though they can display the characteristics of coastal city, but cannot contrast the characteristics of Dalian.

At the same time, most of tourism souvenirs are made rough, lack of sense of design. Sales locations are more concentrated in the railway station, tourist attractions and so on, the prices artificially high, thus keeping people at a distance, and put people off. As we have known now, there are a lot of similar problems not only in Dalian and even in the whole country. Such as the problem of design and production, sales and management, this is a very comprehensive, systemic and important tourism industry. So only to research the development and design feature of a souvenir, can satisfy people's growing taste requirements, while increasing the charm of Dalian.

\section{Design and Development Thoughts of Dalian Characteristic Souvenirs}

\section{A. Design of tourism souvenirs should keep pace with the time and co-prosperity with the rich of tourist industry's content}

Currently, with the development of the times, the development of tourism market forms more ways. As people's living standard rising and the influence of foreign culture, from the way such as visit and tour in the 70's and 80 's develops to today's experience, interactive way of travel in addition to visit and tour. For example, the Dalian International Festival attracts many foreign tourists. And people who take part in the Dalian International Pedestrian Festival are all spontaneous, nearly more than ten thousand each year. So we can tell, today's tourism is not just a visit, but also includes the experience of the city's atmosphere of culture or sports. The Government Work Report of Liaoning province says that, "we should speed up the tourism province construction of hot spring and the construction of hot spring tourism industrial clusters in several areas around Dalian, we also have to construct a number of special tourism towns and leisure bases, then protect and take advantage of the industry cultural heritage". A lot of Russian tourists fixed to living in Dalian more than a month each year, their tourism are mainly hot springs experiencing to experience the hot spring culture of Dalian. And all of these are the new connotation that this era has entrusted to tourism. So, tourism souvenirs should seize the opportunity, find thoughts of design in these emerging tourism project, fill the blank of the market in these areas.

\section{B. The design of the souvenir should be inseparable to the characteristics of Dalian.}

First of all, keep the original features of souvenir market, being a coastal city is the inherent characteristics of Dalian. The sea is the soul of Dalian. And arts and crafts, food or plush toys imitate marine creatures that made around the theme "ocean", is still one of the most important parts in Dalian souvenir market. But, instead of keeping the same, we have to upgrade, transformation and innovation. Many shellfish souvenirs, for example, only get the function of decoration, consumers buy them back to display in the home, because of lacking practical value, they would be discarded when people are tired of watching. Calligraphy and painting are sold in many scenic spots, so we can try to use the same raw materials, shells, rocks etc. to make concept painting, enrich the performance space of raw materials.

At the same time, find out different characteristics of Dalian comparing with other coastal cities. Such as Dalian female troopers, is the world's first female troopers that taken into women rangers, there are also many colorful festivals in Dalian: The Cherry Festival, Garment Festival, Beer Festival, Fireworks Festival, Cherry Blossom Festival, Locust Festival, Beach Culture Festival etc..And the square in Dalian, is also one of the symbols different from any other city of the same type. Such as the Friendly Square which to commemorate the Sino-Soviet friendship, the largest square in Asia--Xinghai Square and other hundreds squares in sizes. In a word, all of these can be used as the design source of Dalian tourism souvenir market during this period. Dalian tourism souvenirs' design should not only to fully embody the characteristics of the coastal city but also reflect the characteristics of Dalian.

\section{The design of the souvenir should develop and expand the city's culture.}

Souvenir's first positioning should be promoting the city's charm, transmitting culture, then increasing profits. Today's consumers, besides taking local specialty and adornment, hope to understand local historic and popular culture in the process of tourism more.

Dalian is defined as a fashion and romantic city, and Lvshun is the witness of history and culture of Dalian. Dahe Hotel, Lvshun Boyang Park named by the anti-Japanese national hero Jin Boyang, the Suqinwang House Site, Lvshun Russian prison, Lvshun Sino-Soviet friendship tower based by the inscription of premier Zhou Enlai in 1955, Lvshun Baiyu Mountain, the tomb of Wan Zhong of Sino-Japanese War in Lvshun and so on, these can be good material of a tourist souvenirs about history and culture. If the research and development of a series of products surrounding these things, it will bring patriotic education significance and can also increase the ladenness of the fashion capital, Dalian. Souvenirs' design and development will be more meaningful if we let tourists at home and abroad to understand Dalian better.

Dalian has rich hot spring resources, as material life level and health consciousness enhancement, hot springs became a kind of popular culture of Dalian formed in recent years. This kind of hot spring culture cooperated with the technology, 
such as traditional Chinese medicine massage, acupuncture, etc. have attracted more foreign visitors of all ages. Souvenirs in this aspect are still blank, there will be some potential space.

\section{Souvenir sales model should be extended}

From its birth to now, the Internet are changing the world constantly, including people's life. Founded in 1999, the Alibaba Group put forward the slogan that "By developing new ways of business to create a completely different world". The way people travel from the single way "reality journey" to the new way of "virtual network tourism ", in virtual tour people can visit scenic spot via the Internet experience, complete tourism experience in the virtual tours without leaving home. IBM launched the virtual tourism project "Beyond time and space" with the imperial palace in Beijing in 2008. In many virtual tours, visitors can choose their own favorite props, set the role of travel, dressed as a princess, a prince, etc.. Thus, souvenirs design can also develop the corresponding goods under the background of the virtual age.
For example, according to the tourists set virtual tourism role of props and so on.

In terms of sales, we can also use more network resources. The transactions of Taobao which is household reached 400 billion RMB in 2010, and reached more than $¥ 30$ billion RMB during only one day on $11.11,2013$. It shows that online consumers are multiplied. Taobao newly added stores which have their own features, and these make a broader space for the development of tourism souvenirs.

\section{References}

[1] Li Shu, "The theory of tourist souvenirs design principles", "Design art" (Journal of art and design of shandong university), January 2008

[2] Chen Zheng Gao, "The government work report", "Liaoning daily", January 2011

[3] Dalian bureau of statistics (NBS): http://www.stats.dl.gov.cn/view.jsp?docid=21549

[4] Jin Hui, "Analysis of the rationality and legitimacy about Dalian city tourism industry policy", DUFE, December 2011 